\title{
Study on the Process of Crafts Manufacturing Koto Gadang District Agam
}

\author{
Yahya and Rendy R S \\ Visual Art \\ Universitas Negeri Padang \\ Padang, Indonesia \\ yahya_tambunan@yahoo.com
}

\begin{abstract}
The purpose of the study describes the types of materials, tools, and processes used in the manufacture of silverware in nagari (village) Koto GadangAgam District. The process of making silver Koto Gadang still using traditional tools. The research method used qualitative descriptive. Data source used primary data and secondary data. Data collection by observation, interview, and documentation. Data analysis is done by: data reduction, data display (presentation of data), drawing conclusions, checking the validity of findings with triangulation technique. The result of observation and interview in nagari Koto GadangAgam Regency, that the process of making silver Koto Gadang by using raw materials from silver seeds are looking for silver collectors. The processing of raw materials is done using traditional equipment until now.
\end{abstract}

Keywords—Manufacturing of handicraft

\section{INTRODUCTION}

West Sumatra possesses silver handicraft business located in the village (nagari) Koto Gadang, District IV Koto, Regency of Agam. Silver handicrafts become an economic source for people around Koto Gadang area such as Guguak Randah and Gantiang. In ancient times silver from Koto Gadang Agam district is also famous for very fine in the process of making it attract the attention of consumers and tourists to have it.

Silver handicrafts that exist in village (nagari) Koto Gadang has two functions, namely as a wear object and decorative objects. Silver handicrafts that function as wear objects such as rings, necklaces, bracelets, earrings and so on. Furthermore, silver handicrafts that function as decorative objects are miniature Minangkabau traditional house, gadang clock, mosque, ship and so on.

Currently Koto Gadang silver handicrafts classified as unique because it still has not changed the good in terms of engineering, design and marketing. They still maintain the making with old techniques because they still appreciate the techniques that have been taught previous craftsmen. Agam ".

Koto Gadang Craft now is much changed. Silver craft industry that once had become the pride of Koto Gadang, is now difficult to find. The artisans who once excited to melt silver into various forms of jewelry, now many are closed, because they feel no longer have hope to develop.

Based on the results of the initial observation of the authors of the original interview Koto Gadang as well as silver craftsmen in the nagari, Mr. Asri approximately 67 years old, who met Sunday October 9, 2016 and then, the sales turnover of silver handicrafts is currently very declining. Whereas once when the craft is growing rapidly, Asri claimed to sell at least 20 pieces of silver jewelry every day in various forms. such as rings, bracelets, necklaces and more, in fact, I was once invited to exhibitions in Singapore and the United States, ".

The respondent's opinion above is reinforced by opinion, Irwanto, dated October 9, 2016, stated that, in a day he usually earn between Rp 200,000 to Rp 250,000. Then with these results, Irwanto can support 6 children, but now, from various types and models of silver handicrafts that exist, not necessarily sold one fruit. Although now, the price of silver is much more expensive than when silver is in demand, but I am difficult to finance the family, said Asri.

Conditions like the above, Asri claimed could no longer rely his life from silverware. Today, although Asri's status is still a silver craftsman, but with conditions like this silver handicraft is no longer used as a staple job. This is what makes silver handicrafts in Koto Gadang no longer idol and difficult to pass on to the younger generation, including the son of Asri father no one is interested to learn and pursue the process of making crafts. If such a situation continues to be worried about silver crafts Koto Gadang eventually disappeared.

The worries about the loss of this silver craft, also seen when the author visited the silver handicraft production house in the village of Koto Gadang, seen silvery production houses quite a lot, but only a few active craftsmen. From the remaining craftsmen handicrafts poses work done is still traditional so that the results can not be much and less quality. When compared 
with other products that exist in the market, tend to be better and look smooth and cheap production costs so as to bring economic impact on crafters. Based on the above problem it is necessary to study about the Process of Making Silver Craft of Koto Gadang Regency.

\section{METHOD}

This research uses qualitative approach. According to Poerwandari (1998) qualitative research is a research that produces and processes descriptive data, obtained through interviews, field notes, pictures, photos video recording and others. In this study emphasizes the closeness with the people and the research situation, so that researchers gain a clear understanding of the reality and real-life conditions of the crafters, and for that purpose is determined: 1) Research subjects or respondents This research is the executor of metal crafts located in Koto Gadang, Kecamatan IV Koto, Kabupaten Agam.2) The research stages, in the research there are two stages of research, namely: Stage of Research Preparation, First the researcher made the interview guidelines based on the meaning of life meaning in accordance with the problems faced subject

This interview guide contains basic questions that will later develop in the interview. Guidelines for interviews that have been compiled, shown to the more expert in this case is research pembibing to get input on the contents of interviewing guidelines. Researchers then look for subjects that match the characteristics of the research subjects. For that before the interview conducted the researcher asked the subject about his / her willingness to be interviewed. After the subject is willing to be interviewed, the researcher makes a deal with the subject about the time and place to conduct the interview. 3) Data collection techniques, in this research, researchers used three techniques of data collection, namely interview, observation and document analysis. a) Interviews, interviews were conducted with artisans as respondents related to research questions and sometimes evolved according to required information. b) Observation, observation that will be done is to subject in the form of product result, craftsman behavior during interview, subject interaction with researcher and things that are considered relevant so that can give additional data to result of interview. c) Document analysis is to see documents and interpret them related to the process of interviews and observations of the process of making handicrafts. 4) Data analysis techniques, Data analysis is the process of compiling or processing data from interviews and observations of crafters to be interpreted further. New data obtained from the observation should be analyzed first by using qualitative data analysis in order to know the meaning of the observation, interview, and documentation study. Then connect the data, reduce the data, the presentation of data and draw conclusions / verivikasi, where the process takes place

In the early stages of circular collection during the study. Since the beginning of the research the researcher has begun by searching the meaning of patterns of artisans' behavior, explanations, possible confirmations, causal grooves and recording regularity. Data, the researcher's focus is still widened and not yet apparent, the observations are still general and broad . After the focus became clearer, the researchers used a more structured observation to get more specific data. Based on the above thinking, the researchers used Miles and Huberman (1992: 73) model, as shown in Figure 1 below:

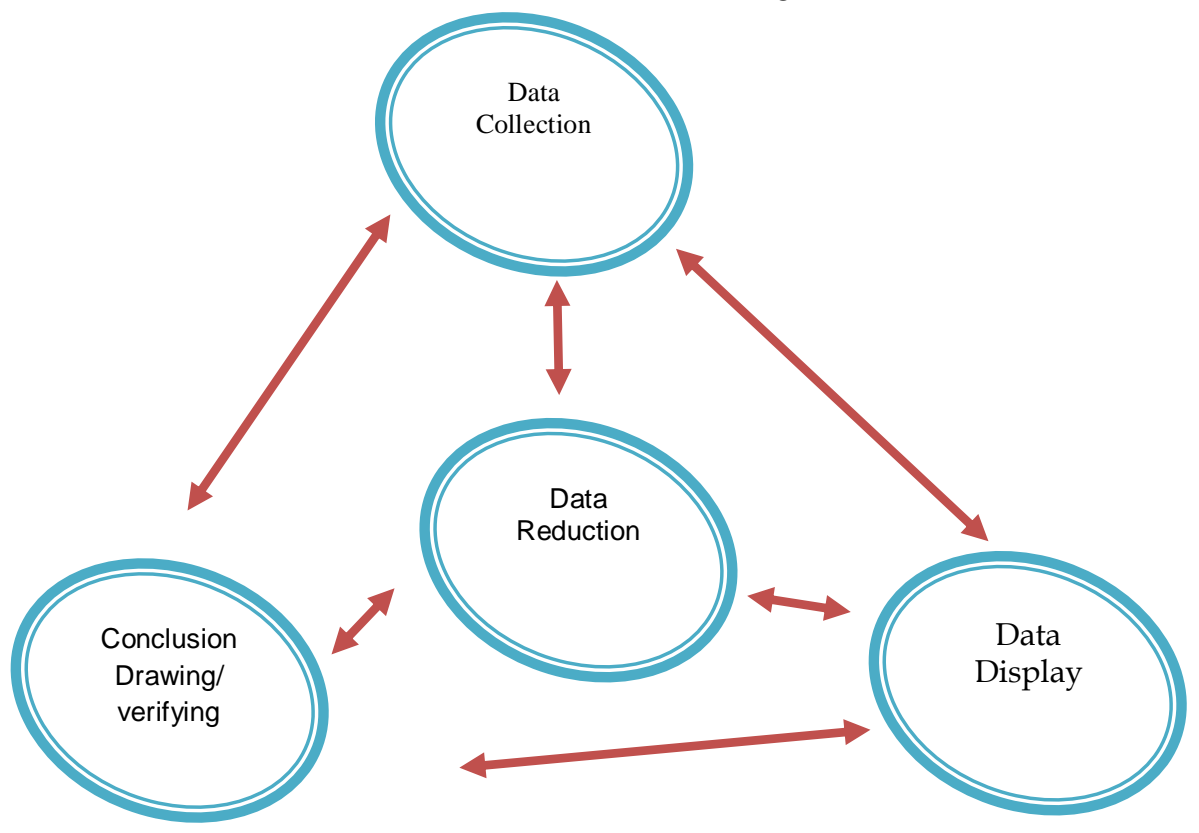

Fig. 1. Data Analysis Components and Models 
Findings

\section{FINDING AND DISCUSSION}

1. Material used

Based on observations and interviews conducted by the researcher to (Asri, 9-10-2016). "That the type of material that can be used by craftsmen to make silver handicraft products is pure 22 carat raw silver without mixing with other materials and merged in Tambika using a tool like a pump that emits sparks called Kapalo kapuih ".

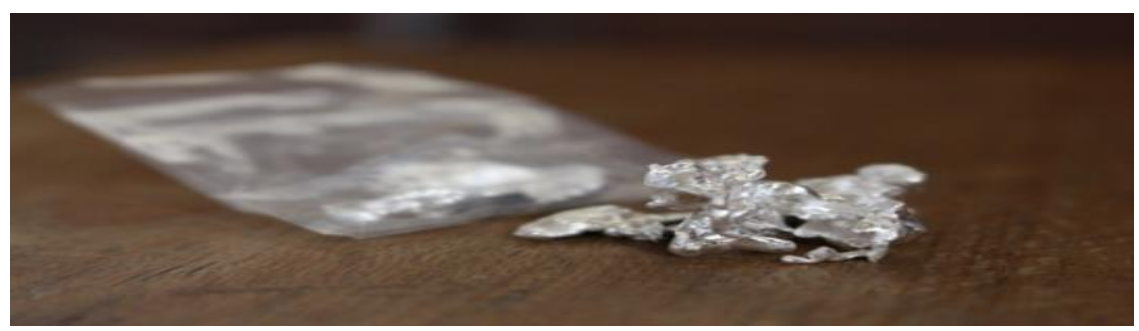

Fig. 2. Raw materials of silver (Photo: Rendhy Ryas Pratama)

Before the silversmiths begin their work they seek and collect all the necessary materials. All the raw materials needed for silver handicrafts are generally obtained by the nagari community of Koto Gadang in the silver / gold collectors in the upper market. After the raw materials are obtained from the sellers, the raw materials are brought to Koto Gadang to be formed and sold as silver jewelry.

Raw materials obtained by craftsmen in the form of raw silver and arriving at Koto Gadang raw silver is melted with hot temperatures so that silver can be molded and molded so it becomes a silver handicraft that is useful as an ornamental object. Statement of the authors above is the conclusion of the statement of some respondents at the time of observation. The following authors describe the statement of some respondents in interviewed about the material of making silver Koto Gadang. This means that the materials used in making silver in Koto Gadang still maintain handmade or handmade non masinal techniques. In the process of crude silver workmanship which became the raw material for making the work melted first so that the process of its formation easier. The type of silver material used is divided into two, namely silver ferrous and non ferrous silver.

\section{Tools Used in the Silver Pengelohan}

A tool is an object that is used to facilitate the work of an object, this equipment usually uses simple tools like a home industry. The results of monitoring in the field of crafts work done at a certain corner of the room. "All the equipment used should be in accordance with the utility and basic functions of each tool, because without the equipment then all the difficult work will be difficult because the problems found in the work process are not all solvable only by relying on energy and empty hands. (interview Asri, 9-10-2016). The statement is reinforced by the interview (Iskandar, 30-10-2016) states that the tool is an object used to do something whose function is to facilitate the work. Tools are also called tools or furniture. Once upon a time humans argued that tools are identical with humans. Because only humans have roots and minds so have roots and minds that have the ability to produce a work of creation

Two opinions above concluded that the tool is suatau media to facilitate someone to do a pekerajaan. The tool is also called the tool of a job what else the work is constrained by a problem that can not be solved with empty hands. With the existence of work equipment will make the artisans to ease the process of making crafts or works. The above equipment statement focuses on the author to the equipment for the manufacture of silver crafts from the beginning of the process of raw materials to the finishing of silver handicrafts that are useful as jewelry, home appliance, and as souvenirs.

The following describes the types of equipment used to make silverware. Tambika or pottery is a kind of small container where a silver fuser is made of clay material that has been burned.

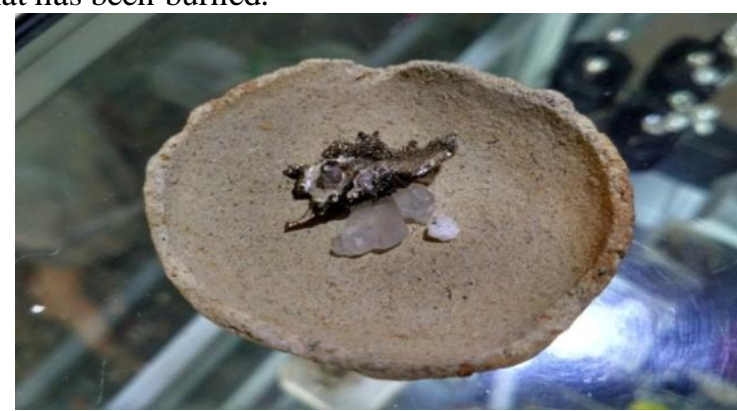

Fig. 3. Tambika (silver fuser) Photo: Rendhy Ryas Pratama 
According to the interview, (Asri, 9-10-2016) mentions that pottery or tambika is an object made of clay that is burned and glazed. This opinion is reinforced by the interview (Iskandar, 30-10-2016) states that pottery or tambika is a banda where the raw material uses clay made by craftsmen. Pottery is made by forming clay into a container and then burned to make useful tools to help human life. One of the uses of this pottery or pottery is as a container for melting the silver that has been melted by using a hot temperature fired by kapuih kapoih as a fire spray so that the silver is liquid. Once melted the silver that is in the tambika becomes round and put into the water.

Various kinds of household items such as scissors, pliers of various sizes:

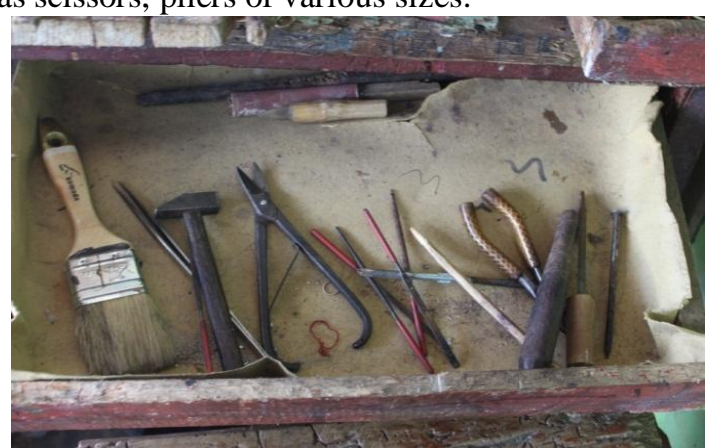

Fig. 4. Household tools (Photo: Rendhy Ryas Pratama)

The paddle foundation is made of wood and steel. The foundation of this bat is made in such a way, because the needs of the craftsmen are required to work as much as possible.

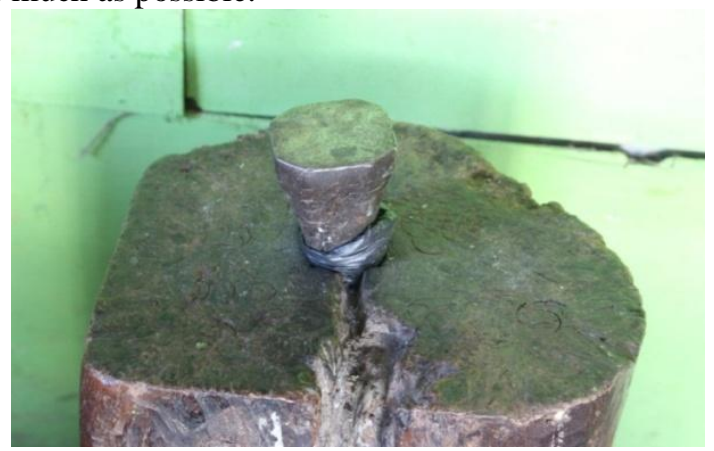

Fig. 5. Bending Platform (Photo: Rendhy Ryas Pratama)

The result of the interview with Asri, 9-10-2016, states that the silver craft before the pattern is made into a desired shape, then the metal material that had been melted and soaked then the metal is placed on a steel iron in the pinned on a piece of pine wood which serves as a place of steel or place of silver beating foundation. The respondent's opinion above is reinforced by another respondent (Iskandar 30-10-2016) stated that the silver holder base is made of steel, and there are supporting media in the form of pieces of pine wood that serve as the seat of the steel. The silver bucket ground is used as a batter or silver splinting place so it makes it easier to form a pattern that will be made into valuable jewelry.

The statement of the two respondents above can be deduced that the place of silver beater foundation is made of steel bar which is pinned on a round piece of pine wood. This object is a place of silver beater base so that it becomes flat and useful to facilitate craftsmen to freeze the process of formation of archetype, so it becomes a jewelry that is useful and worth selling. Kapuih is a circuit that serves as a pump which there are several components such as head soldier, wind tube, and oil tube.

\section{The Process of Making Silver Crafts}

Koto Gadang silverware produces silver in the form of jewelry in the form of ring-shaped jewelry, bracelets, and necklaces that function as ornamental objects for women in general. For men also available jewelry forms such as rings, bracelets, and kalaung but the amount is not as much as female jewelry. Here the author describes the findings of the process of making silver Koto Gadang jewelry ring-shaped. The process of making Koto Gadang silverware as follows: 1) The first process is done before entering into the process of formation globally, the craftsman must create a design or sketch of silver handicraft which is useful as a jewelry according to its function by considering the composition, accentuation and beauty in the form ring jewelry. 2) Declare to prepare pump for burner (kapuih). Kapuih is used to melt raw silver in the form of small seeds with very hot temperatures issued by the pump and fire contained on the solder head. 3) According to the interview (Iskan 30-10-2016) stated melt or melt the silver in a ceramic tile which serves as a medium for storing the fluid in the heat. 4) Once the raw silver has been melted into a liquid that coagulates into one then the silver is poured into a brick that is concave in order that the silver fluid becomes a shrub or a lump intact without any air trapped in the silver that has been chilled. 5) The silver that was already shaped 
like a gepengan will be processed again into a mipih chip. The process by the way at hit using a hammer and it is necessary also a grounding batter for silver bars is easy to process. 6) After the silver that has been melted into a bar, then placed to the base of the baton made of wood in the middle of his copper iron in copper and at the mipih it is aimed so that the silver that had been in the pipeliness by using a hammer will be more perfect flat . 7) Declare that the silver that had been flattened by the way at the hence then at the clock again on the paddle so that the shape of a spoon on the tip. It aims to facilitate the formation of a ring body that will be in place of ornament motifs as his hiasanya. 8) The next step of the process of reheating the silver that has been hit more mipih.

\section{Discussion}

Metal craft is a craft art whose processes use smelting, casting, molding, and stitching techniques that connect metal parts by adding other metal fluids. Metal crafts are usually used as jewelry, souvenirs, and decorations. The media used in crystals such as iron, copper, aluminum, gold, brass, bronze, and silver.

Silver handicrafts that exist in nagari Koto Gadang has two functions, namely as a wear object and decorative objects. Silver handicrafts that function as a wear object such as rings, necklaces, bracelets, earrings and the like. Furthermore crafts that function as a decorative object that is miniature Minangkabau traditional house, clock gadang, mosque, ship and so on. Koto Gadang silverware has its own advantages because it is still not menggalami changes that can be seen in terms of engineering and design. Koto Gadang Craftsmanship of Agam Regency still maintains the making with old technique karenamasih considering the kanteknik that has been triggered by previous craftsmen.

The process of making silver Koto Gadang still retains the traditional way (manual). In Koto Gadang area there are about 10-20 craftsmen who are still active. According to the community around the former there are so many people who act as silver craftsmen, because of the rapid development of the age and technology, the silversmiths began to decrease. Because of that, the craftsmen of silver Koto Gadang at the present moment is very minimal and they judge many other work besides crafting silver that better guarantee their lives given the lack of public interest about silver handicrafts except middle and upper class society.

Koto Gadang silver handicraft is a traditional handicraft of a process of making goods by using hand and simple tool available in household environment and studied from generation to generation with raw material available around the area of residence (Bais in Kamal 2016: 6) the statement is reinforced by respondents interview (Asri 9-10-16) stated initially Koto Gadang silver handicraft used for customs needs and as a complement of traditional clothing Koto Gadang. This work they do just to melanjtkan ancestral heritage which then bequeathed to their grandchildren.

Based on the above data explanation kriyalogammerupakansenikriya manaprosesnya using smelting techniques, casting, molding process, and solder technique that connects the metal parts by adding another metal liquid. Metal crafts are usually used as jewelry, souvenirs, and decorations. Media used in metal crafts such as iron, copper, aluminum, gold, brass, bronze, and silver.

Craftsmen in the village Koto Gadang has two functions, namely as a wear object and decorative objects. Silver handicrafts that function as a wear object such as rings, necklaces, bracelets, earrings and the like. Furthermore, silver handicrafts that function as an ornamental object that is miniature custom house Minangkabau, clock gadang, mosque, ship and so on. Koto Gadang silverware has a unique because it still maintains the tradition both in terms of engineering and design. The crafters remain consistent with what was taught by the previous crafters even though the craft technology has grown.

The process of making silver Koto Gadang still retains the traditional way (manual). In Koto Gadang area there are about 10-20 craftsmen who are still active. According to the society around the past there are many people who act as silver artisans, because of the rapid development of the era and technology, the silver artisans began to decrease. Because of that, the craftsmen of silver Koto Gadang at the present moment is very minimal and they judge many other work besides crafting silver that better guarantee their lives given the lack of public interest about silver handicrafts except middle and upper class society. Koto Gadang silver handicraft is a traditional handicraft of a process of making goods using hand and simple tools available in household environment and studied from generation to generation with the raw material available around the area of residence (Bais in Kamal 2016: 6) the statement is reinforced by respondents (Asri 9-10-16) stated that initially Koto Gadang silver handicraft is used for customs needs and as a complement of traditional clothes of Koto Gadang. This work they do just to continue the ancestral heritage which is then passed on to their grandchildren.

\section{CONCLUSION AND RECOMMENDATION}

Based on the results of research conducted on silver Koto Gadang Agam there are three kinds of jewelry products, namely: rings, bracelets, and necklaces. In addition silver Koto Gadang also produces souvenirs as home decoration, wedding souvenirs, and displays. Koto Gadang silver handicraft established since 1918 Dutch colonial era. From the year of silver crafts Koto Gadang up to now still maintain the techniques and traditional ways in processing silver handicraft process. After doing this research then the authors get new data and new findings with the following conclusions. 
1. Materials used in the process of making silver handicrafts in the form of jewelry or souvenirs using raw materials in the form of silver in the form of seeds, gilding material that serves as a material to cover a surface that is not flat, cast material that serves as auxiliary materials fusion taro tools, scales, and round molds. silver

2. In addition to the above materials there are also some equipment that serves as a medium for the process of making silver Koto Gadang. The tools are in the form of tambika, various kinds of household appliances, paddle pads, kapuih, big pliers, iron penarik silver, miser, tweezers, gold saws, mold of bricks, ring batten

3. The process of making silver Koto Gadang must go through several processes as follows: make design, prepare pump kapuihmelebur silver, pour the silver liquid into brick mold, silver spinning, heating using pump kapuih, choose design, sawing motif according to design pattern made, folds, soldering, smoothed using a miser, put a gem, and the final stage of cleaning a silver craft.

\section{References}

Budi Ahmadi. (2008). Study About Woven Pandanus in Enok Sub-district Indragir Hilir Riau Province (Thesis). Padang. Program Strata I UNP Padang

Directorate General of Tourism, Introduction to Tourism of Indonesia, (Jakarta: 1975), page 9

Djamal M. (2015). Qualitative Research Paradigm, Yogyakarta: Publisher Pustaka Belajar

Kusnadi, Role of Arts Crafts (Tradisioanal and new) in development, cultural analysis, (department P and K year III No.2 $1982 / 1983)$, page 42

Moleong, (2005). Method Qualitative Research Bandung: PT RemajaRosdaKarya.

Nasir, Yopi. (2013). Jagat Handicraft. Jakarta: PT BumiAksara.

Nawawi. (1991). ResearchApplying Yogyakarta: GadjahMadaUniversity press.

Oka A. Yoeti, Tourism Marketing, Bandung: Publisher Angkasa, 1980). Page 52

Philip Kotler, Marketing Management Analysis, Planning and Control, translated by Drs. Radio Sunu lecturer of UGM Economics Faculty, (Yogyakarta: Bulak Sumut, early July 1980). Page 4

Fourth Language Language Center. (2008). KBBI. Ministry of Education. Jakarta: Gramedia http; // anisakerajinanperak. Blogspot.com/ 2015/03 / understanding-of-craft-silver. html http / www.jenis-jenis-craft-silver-based-how-manufacture.html 